\title{
Dendritic Pathology: An Overview of Golgi Studies in Man
}

\author{
Venkita Jagadha and Laurence E. Becker
}

\begin{abstract}
Study of dendritic morphology through Golgi impregnation techniques has significantly furthered our understanding of neuronal development, maturation, and senescence. It has also provided insight into the pathogenesis of a wide spectrum of disease processes ranging from brain malformations to degenerative disorders. Golgi impregnation remains virtually the only method for demonstrating dendritic morphology. It delineates the profile of the individual neuron and its dendritic ramifications with unsurpassed clarity. Although it has been widely applied to experimental neuroscience involving animal tissue, its application to human material has been limited. This review summarizes the information on dendritic development and pathology in the human brain revealed by the use of the Golgi method.
\end{abstract}

\begin{abstract}
RÉSUMÉ: Pathologie dendritique: Une revue des études de l'appareil de Golgi chez l'humain L'étude de la morphologie dendritique par les techniques d'imprégnation de l'appareil de Golgi a amélioré significativement notre compréhension du développement, de la maturation et de la sénescence neuronale ainsi que de la pathogénèse d'un large éventail de maladies allant des malformations du cerveau aux maladies dégénératives. L'imprégnation de l'appareil de Golgi demeure la seule méthode pour mettre en évidence la morphologie dendritique. Cette technique identifie le profile de chaque neurone et de ses ramifications dendritiques avec une clarté insurpassée. Bien que cette technique ait été appliquée extensivement sur des tissus animaux dans la recherche en sciences neurologiques expérimentales, son application aux tissus humains est demeurée limitée. La présente revue est un sommaire des informations ainsi recueillies sur le développement dendritique et la pathologie du cerveau humain.
\end{abstract}

Can. J. Neurol. Sci. 1989: 16:4I-50

For normal development of the nervous system, neurons must be generated in sufficient numbers at the right time, assume the proper positions in the cortex, acquire the appropriate geometry, and synapse with specific cells. The extensively ramifying dendrites form the major part of the receptive surface of the neuron accounting for about $95 \%$ of the total surface. Development of dendrites and differentiation of dendritic spines are critical morphogenetic events in the developmental sequence of neuronal maturation. ${ }^{1-5}$ Dendrites provide the major proportion of the membrane surface area for integration of synaptic inputs, ${ }^{6}$ and dendritic spines are postsynaptic targets for a variety of afferent projections to cortical neurons. ${ }^{7}$ An understanding of normal dendritic development in the human cortex provides a background for insight into the pathobiologic basis of disease.

Conventional neuropathologic studies generally give no direct information about the morphologic status of dendrites. Yet, dendritic pathology may be pronounced despite the absence of conventional histologic findings. In this context Golgi impregnation becomes an indispensable tool to demonstrate cortical architecture. For almost a century, it has been recog- nized as one of the best and probably most elegant procedures to provide unsurpassed clarity and delineation of the shape and spatial arrangement of axons and dendrites. ${ }^{8-10}$ It is applicable to central nervous system structures as well as peripheral sense organs and free nerve endings. Selected nerve cells, dendrites, axons, and fine terminal branches become dark brown against a golden yellow background. The value of the technique lies in its unique ability to stain the entire neuron (Figure 1), allowing complete studies of individual neurons. However, only about $10 \%$ of neurons are stained. Because the tissues are thick (50$200 \mu \mathrm{m}$ ), the dendritic tree cannot be visualized in one plane. By superimposing camera-lucida drawings, one can follow dendritic ramifications and tortuous axonal pathways (Figure 2).

The general principles of the techniques of Golgi staining have been reviewed in detail elsewhere $8-15$ and will be only briefly mentioned here. The procedure involves either silver Golgi techniques with precipitation of silver chromate within tissues (the classic rapid Golgi method and the Hoyer Bolton method) or mercurial Golgi techniques. The Golgi technique may be combined with electron microscopy or other neurohistologic and autoradiographic methods. ${ }^{15}$ Specially adapted proce-

From the Division of Neuropathology (Department of Pathology), The Hospital for Sick Children and the University of Toronto, Toronto Received June 9, 1987. Accepted in final form August 29, 1988

Reprint requests to: Dr. L. E. Becker, Division of Neuropathology, The Hospital for Sick Children, 555 University Ave., Toronto, Ontario, Canada M5G 1 X8 


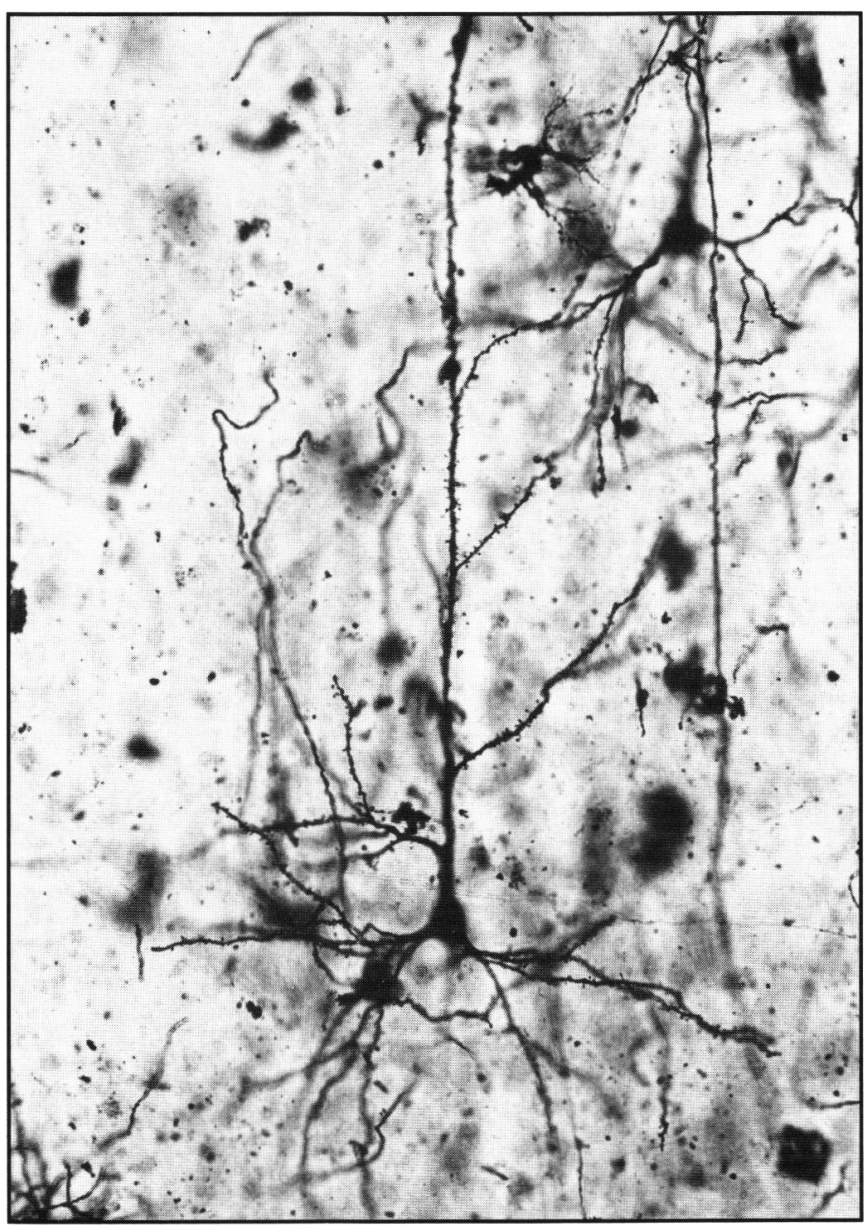

Figure I-An example of a Golgi impregnated pyramidal cell. X 200.

dures to impregnate sections $60-200 \mu \mathrm{m}$ thick instead of the usual small tissue slices have also been designed. ${ }^{16}$ Inconsistencies in staining and impregnation lead to difficulties in interpretation, especially when the tissues are not processed immediately, as is often the case with postmortem material. ${ }^{17}$

The Golgi method revealed its power through the classic studies of investigators such as Ramón Y Cajal. ${ }^{18}$ In the period between the two world wars, the method was used progressively less frequently, ${ }^{9}$ but after World War II, there was a resurgence of interest. The method has been extensively applied in experimental neuroscience. However, study of human material has remained relatively restricted. In the last two decades there has been renewed appreciation of the value of the Golgi method, since it is virtually the only one that can be used to examine dendrites in the human brain. The highly selective and arbitrary nature of neuronal impregnation has limited its use in diagnostic neuropathology. Nevertheless, in selected situations, the Golgi method is the only means of detecting pathologic alteration. In this review we summarize the salient literature on human Golgi studies.

\section{NeUronal Development}

Some of the most significant contributions of the application of the Golgi method pertain to the sequence of normal dendritic differentiation in the human fetus (Figure 2).4,5,19-30 Hippocampus, motor cortex, and visual cortex have been described in detail.

The dendritic morphogenesis of the immature human hippocampus has been documented by Purpura. ${ }^{5}$ At 14 weeks gestational age (GA), apical dendrites are well differentiated in the hippocampal pyramidal neurons but basal dendrites are barely detectable. Maximal dendritic growth and development occur between 18 and 24 weeks GA. From 18 to 22 weeks GA, the dendrites exhibit several growth characteristics including marked irregularities in length and calibre of dendritic shafts, preterminal and terminal growth cones, and multiple varicosities on newly formed dendrites.

Within the various subfields of the hippocampus, neurons may exhibit variable dendritic differentiation at any one time. In the 18- to 20-week-old fetus, the deep pyramidal neurons of the $\mathrm{CA}_{1}$ region have acquired extensive apical dendrites while the superficial neurons are poorly developed. In the hippocampus, the area $\mathrm{CA}_{3}$ lags somewhat behind the other two sectors.

The fascia dentata provides the most striking example of regional variation in growth and differentiation in neurons of similar types at one phase of development. The initial differentiation of the granular and polymorphic layers of the dentate gyrus progresses from a lateral to a medial gradient. This gradient follows closely the sequence of granule cell development: granule cells of the suprapyramidal limb are generated earlier than those in the infrapyramidal segment. Development also proceeds from the outer edge of both limbs toward the deeper layers of the granular cell layer.

Golgi studies of the prenatal and early postnatal ontogenesis of the motor cortex $x^{4,21-23,31}$ have shown that the development and subsequent maturation of efferent cortical neurons and cortical layering result from the arrival of various afferent fibers in the cortex. Layer 1 is the first level of the cortex to mature. The Cajal-Retzius neurons develop earliest and, with their afferents, form the first distinct neuronal chain found in cortical ontogenesis. In the 5-month-old fetus layer 1 is more developed than the rest of the cortex. Except at $400-500 \mu \mathrm{m}$, the neurons of the cortical gray matter are immature at the bipolar stage of development. At these depths, pyramidal cells of layer 5 are developing and, below them, the neuronal elements of layer 6 are identifiable. The development and maturation of interneurons of the motor cortex parallel those of the efferent neurons with which they establish intracortical neuronal chains. By 5 months GA, the internal band of Baillarger is identifiable.

The human motor cortex is characterized by postnatal reduction of layer 4. This is a developmental peculiarity of this cortical region and is due to marked postnatal growth of layers 3 and 5 into layer 4 territory. Development of pyramidal and basket cells in layers 2, 3, and 5 is also marked. The pericellular baskets around layer 5 giant pyramidal neurons in the human motor cortex have two sources. The intrinsic source is from the cortical basket cells; the extrinsic source is from afferent fibers, presumably originating in the thalamus.

The development of visual cortex appears to lag behind that of the hippocampus and the motor cortex by 4 to 6 weeks during antenatal development. ${ }^{24,28,29} \mathrm{We}^{28}$ have described the morphology of the visual cortex in the human infant from 14 weeks GA to 6 months of postnatal age. Except for the Cajal-Retzius 


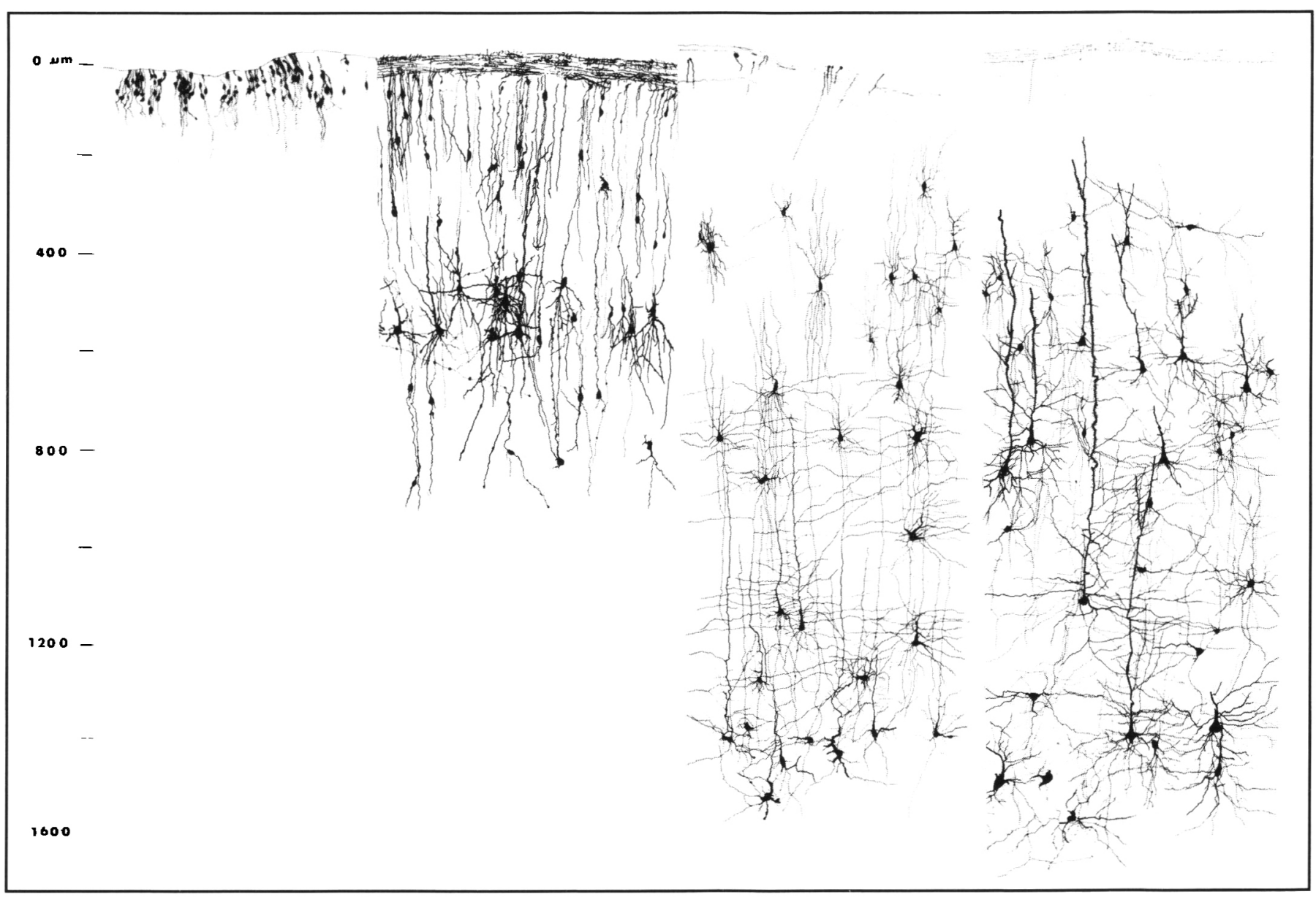

Figure 2 - Composite camera lucida drawings of Golgi impregnations, showing neuronal maturation in the human visual cortex. $A=14$ weeks gestation. $B=24$ weeks gestation. $C=$ neonate. $D=4$ months old.

cells, the neurons matured first in the deeper layers. At about 19 weeks GA, definite neurons were identified in layers 3 and 5 . A gradual transformation from immature bipolar cells to pyramidal cells was identified, with the appearance of characteristic pyramidal cells by 24 weeks (Figure 2).

Quantitation of spines revealed that, with maturation, the number of spines decreased in the proximal parts and increased in the distal parts of apical and basal dendrites. ${ }^{28}$ At or before 40 weeks gestation, the dendritic tree reached $35 \%$ of the maximum for layer 3 neurons compared with 55\% for layer 5 neurons. ${ }^{29}$ In layer 5 , dendritic branching occurred earlier and growth continued to be more advanced than in layer $3 .^{29}$

Purpura 24,25 showed a structure-function correlation in developing visual cortical neurons and the pattern of visual evoked responses (VER). In young, preterm infants (24 to 25 weeks GA), VER recorded at the occiput exhibited an initial long-latency negativity and by 27 to 28 weeks GA a small positive wave preceded the long-latency negativity. This change in the initial component of VER corresponds to dramatic morphogenetic changes, occurring at about 27 to 28 weeks GA, that involve dendritic arborization and development of spines.

Golgi studies have described the cytoarchitectonics and dendritic ramifications of the neurons in auditory cortex, ${ }^{32-34}$ and various spinal and cranial somatic nuclei. ${ }^{35}$
Several studies focus on dendritic spine differentiation and morphology. 5,36-38 The extent to which dendritic development and dendritic spine differentiation occur in the antenatal period is noteworthy. The fact that much of the increase in dendritic surface occurs during the last trimester renders dendritic developmental processes in the preterm infant particularly vulnerable to noxious influences. Purpura ${ }^{5}$ described extraordinarily long dendrites of some dentate granules in an infant born at 29 weeks GA with a survival of 4 weeks on life support systems. The dendritic development was not interrupted or compromised. He also described very prominent basal dendrites on medium and large pyramidal neurons in an infant who was born at 36 weeks and survived for 2 days. $^{5}$ In contrast, we $\mathrm{e}^{38}$ observed retardation of neuronal maturation in premature infants compared with that in term infants of the same postconceptional age: in 2 of 10 infants, the morphology of the dendrites and spines was markedly abnormal, while in 2 other cases, many immature neurons were found, possibly indicating arrested maturation. While the actual mechanism leading to dendritic aberrations is unknown in premature infants, hypoxic insults could be contributory.

Dendritic spine development and synaptogenesis are prominent during the third trimester and reach maturation midway through the first postnatal year. 5,36 Marin-Padilla ${ }^{36}$ showed that 
the number of apical dendritic spines in the pyramidal cells of layer 5 increased with age. Through most of the length of the dendrite, the number of spines increased with distance from the soma; the increase was rapid at first, then slower, then rapid again; toward the distal end of the dendrite the spine count decreased.

Purpura ${ }^{5}$ found dramatic morphological alterations in the apical dendritic shafts of the proximal segments of motor cortex neurons during the latter half of gestation. In the 18-week-old fetus, a few long, thin, filopodium-like processes with variable terminal expansions were detectable. By 26 weeks GA, many more long, thin processes appeared, which predominated at 33 weeks GA. At this stage, a few mushroom-shaped and stubby spines were detectable. In the early postnatal period the proportion of long-thin, short-thin, and mushroom-shaped spines changed strikingly. The 6-month-old infant showed fewer longthin spines than the preterm infant. The trend toward a progressive increase in stubby spines was maintained until 7 years of age.

\section{Dendritic Pathology in Mental Retardation}

Marin-Padilla ${ }^{39,40}$ first pointed out abnormalities of spine development in infants with chromosomal aberrations associated with mental retardation. He described both very long, thin, tortuous spines and short, thin, barely detectable spines. He reported the presence of bizarre, long, thin, cortical dendritic spines in a stillborn infant with trisomy 13-15 and commented on their similarity to the developing spines of very immature neurons. The absence of small, stubby spines in these conditions may reflect failure of spine generation or transformation from the long to the stubby forms. 39,40

In children with unclassified mental retardation, similar abnormalities may be seen. ${ }^{41-45}$ Huttenlocher ${ }^{43}$ found defects in number, length, and spatial arrangement of dendrites and synapses in 6 cases. Thus, dendritic spine "dysgenesis" is common in various mental defects; the degree of spine loss and abnormality appears to be related to age and severity of retardation. ${ }^{42}$

Dendritic abnormalities have also been found in Down's syndrome. ${ }^{46-50} \mathrm{We}^{48}$ documented similar neuronal morphology and spine counts in fetuses with trisomy 21 and in controls, while neonates and older infants showed shorter basal dendrites and decreased numbers of spines with altered morphology. Our analysis of dendritic branching development in Down's syndrome showed a pattern of arborization different from that of age-matched control brains. ${ }^{50}$ In the infantile period, the total number of dendritic intersections (within concentric circles at $20-\mu \mathrm{m}$ intervals for the cell body) was greater than in the control group; in the juvenile period it was significantly reduced. Total mean dendritic length (apical plus basal) was reduced in layer 3 cells by almost $50 \%$ from the infantile to the juvenile group, in contrast to the $65 \%$ increase observed in controls. Thus, unlike the normal expansion of dendrites observed in controls, dendritic atrophy is seen in early childhood in Down's syndrome.

Marin-Padilla ${ }^{46}$ described the presence of various spine aberrations, including unusually long spines, very short spines, and a reduced number of spines, in Down's syndrome. Suetsugu and Mehraein $^{47}$ demonstrated a diminution in the number of spines in the middle and distal segments of apical dendrites in neurons of the hippocampus and cingulate gyrus. Fabregues and Ferrer ${ }^{49}$ described abnormal fine and stubby perisomatic processes in nonpyramidal neurons.

Williams and Matthysse $\mathrm{e}^{51}$ found age-related degeneration of the dendrites in the neocortical and hippocampal pyramidal neurons and dentate granule cells in Down's syndrome. They studied 7 patients with Down's syndrome between 6 and 64 years of age. Qualitatively, they did not find striking alterations of spine morphology in the neocortical pyramidal cells. Their quantitative data differ from those of other reports in the literature. ${ }^{46-50}$ In their study, the total dendritic extent was greater in two 6year-old children who had Down's syndrome than in controls 16 years or older. However, young adults (25-31 years) had values similar to those for controls, which decrease sharply later in life as changes of Alzheimer's disease become severe. They concluded that the dendritic extent in Down's syndrome is not strikingly different from the control group until the fourth decade when histologic changes of Alzheimer's disease invariably set in.

\section{METABOLIC Disorders}

Profound mental retardation and neurobehavioral deterioration are frequent in a variety of neuronal storage diseases. In these conditions, the neurons often show swollen perikarya and torpedo-like swellings of axons (Figure 3). These distortions are associated with progressive accumulation of uncatabolized substrates. Studies using the Golgi and other methods have shown that variation in the neuronal geometry and development of aberrant synapses may contribute to the neurobehavioral defect in these diseases. ${ }^{45,52-63}$ Purpura and Suzuki ${ }^{52}$ proposed that meganeurites and their synapses contributed to the neuronal dysfunction by altering the electrical properties of the neuron. In many cases, the total surface area of a meganeurite was greater than the surface of the cell body itself.

The progressive nature of the development of meganeurites is also illustrated by Purpura ${ }^{45}$ in his report of a child with $\mathrm{GM}_{2}$ gangliosidosis ( $\mathrm{AB}$ variant) who showed relatively minimal alterations at 14 months of age but experienced a dramatic progression of changes leading to extremely large meganeurites by the time of death 30 months later. Williams and associates ${ }^{56}$ studied a case of Krabbe's disease but found no specific dendritic pathology.

Golgi impregnations in neuronal ceroid lipofuscinosis have shown variable pathology. $53,55,57,60$ In the case of a late infantile form of neuronal ceroid lipofuscinosis described by Williams and colleagues, ${ }^{53}$ a fusiform enlargement of proximal axon segments of pyramidal and polymorphic neurons was found. Meganeurites have also been described in other reports. ${ }^{59,60}$ In a case of Kufs' disease, Ferrer et al ${ }^{57}$ described enlarged axon hillocks. Braak and Goebel ${ }^{55}$ showed giant axonal dilations of the pyramidal neurons and severe reduction in neuronal counts in the isocortex of a case of juvenile neuronal ceroid lipofuscinosis.

We ${ }^{63}$ have observed meganeurite formation along with diminished dendritic arborization in the visual cortex in 2 siblings with an unusual association of infantile osteopetrosis and neuronal accumulation of ceroid lipofuscin. We also observed dendritic abnormalities in patients with sialidosis, and meganeurites in Sanfilippo's syndrome. ${ }^{62}$ 


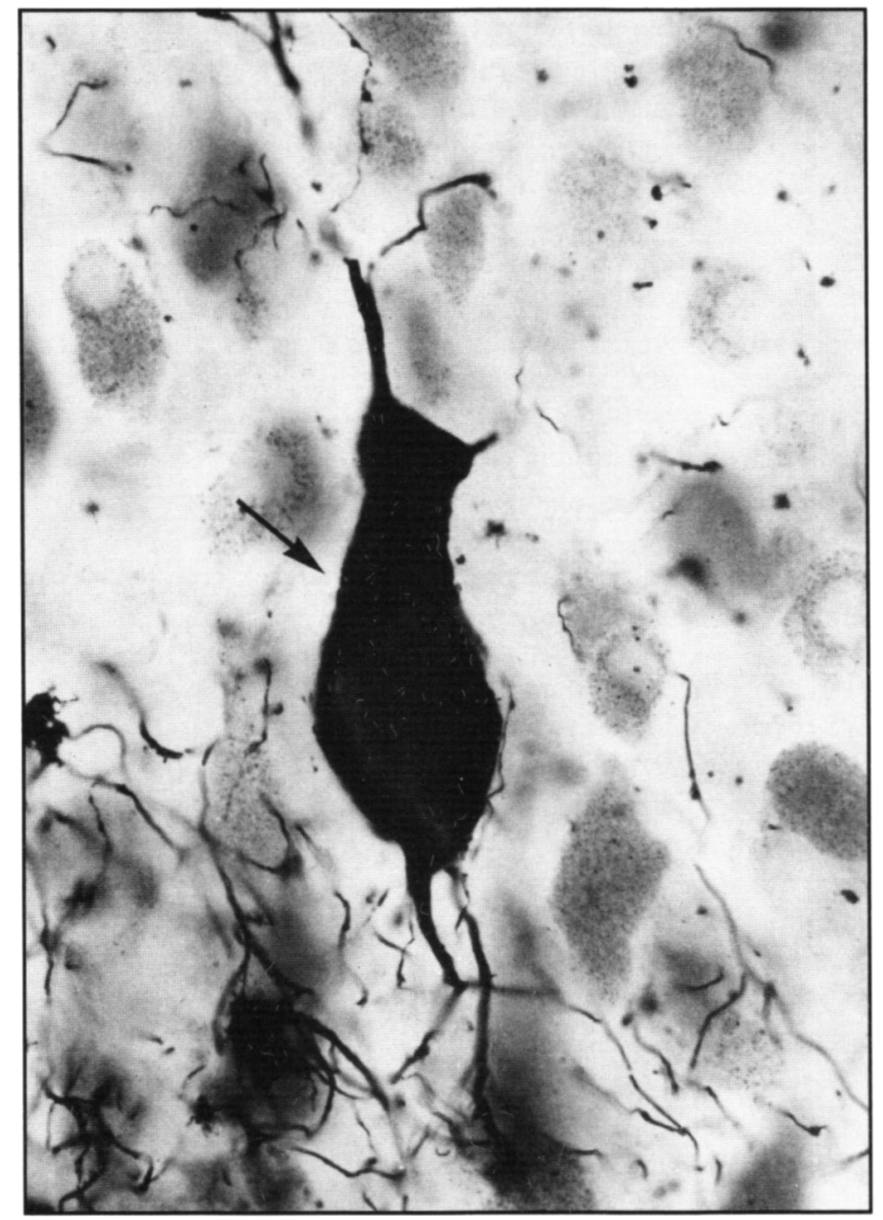

Figure 3 - (Rapid Golgi $\times 320$ ). Meganeurite formation (arrow) in Tay-Sachs disease.

Golgi analysis of various leukodystrophies is of interest. In 2 patients who had severe central demyelination with confirmed metachromatic leukodystrophy and adrenoleukodystrophy, we 64 found significant diminution of dendritic spines and branch intersections. In 1 case each of Cockayne's disease and Pelizaeus-Merzbacher disease, we ${ }^{64}$ found a reduction in dendritic spines. The degree of mental retardation in some of these diseases is striking even though the myelin loss may not be very severe; thus, the variations in dendritic morphology are of interest although their significance is as yet unknown.

Cerebellar Purkinje cell abnormalities, including loss of branchlet spines and abnormal thickenings of Purkinje cell dendrites, may be found in various disorders. 65,66 One of the most striking examples of Purkinje cell pathology is seen in Menkes' kinky hair disease. ${ }^{45,67-72}$ In the mid-gestational human fetus, the bodies of Purkinje cells may exhibit fine perisomatic processes of somatic pseudopodia, some of which are in postsynaptic relation to climbing fibers. ${ }^{73} \mathrm{By}$ late gestation these disappear, the soma acquires a smooth contour, and climbing fiber contacts are made exclusively with small spines of primary dendrites. In Menkes' disease, the Purkinje cells show somatic sprouts, which are polydendritic processes containing dendriticlike spines. ${ }^{70}$ The presence of these processes suggests an interference with developmental mechanisms regulating site-specific surface membrane characteristics. This phenomenon has also been observed by Purpura in the cerebellum of children with Down's syndrome. ${ }^{45}$

In untreated phenylketonuria, which is associated with severe mental retardation, Bauman and Kemper ${ }^{74.75}$ have shown a reduction in the number, length, and degree of arborization of dendrites as well as a paucity of spines in the cerebral cortex compared with the number in age-matched controls.

\section{Cerebral Malformations}

The Golgi method has been used to study the neuronal profiles and cellular organization of several cerebral malformations and miscellaneous disorders. ${ }^{76-89}$ The primary pathologic process in microgyria may be abnormal neuronal migration or postmigratory necrosis affecting a restricted laminar zone. ${ }^{76,82}$ In some cases of microgyria, a zone of necrosis has been described at the midcortical level, destroying predominantly the stellate neurons of layer 4 and some adjacent neurons in layers 3 and 5 , and leaving a dense glial scar in this zone. ${ }^{81}$ Although somewhat reduced in size, the surviving neurons in layers 2 through 4 are essentially normal in relative position and dendritic geometry and morphology. The apical dendrites of the pyramidal neurons below the scar are tangentially rather than radially aligned. 80

In lissencephaly, a true cortical zone composed of neurons of the lower cortical layers that have completed migration is separated by the glial scar from the subcortical zone of neurons arrested in their migration. ${ }^{77.78 .81}$ We studied the dendritic morphology in an 18-month-old girl who had classical lissencephaly (unpublished data). The cortical lamination consisted of 4 layers: molecular, superficial and cellular, sparse and cellular, and deep and cellular. In the molecular layer, there were several pyramidal neurons with small soma and short, obliquely arranged dendrites. Reduced numbers of spines were found on both apical and basal dendrites.

In a 16-month-old girl who had Walker's lissencephaly, a familial condition with convolution anomalies and ocular lesions such as microphthalmia and retinal dysplasia, we found an irregular neuronal arrangement and orientation in the polymicrogyric cortex. The dendritic abnormalities included reduced numbers of spines; short, thin spines; and abnormal branching. Our Golgi studies have also revealed short basal dendrites and irregularly shaped stellate neurons in a polymicrogyric cortex from a 10-year-old girl with Fukuyama's congenital muscular dystrophy (unpublished data). Ferrer ${ }^{87}$ showed a variable degree of cellular damage and structural disorganization of the cerebral mantle in a Golgi analysis of unlayered polymicrogyria located at the borders of a porencephalic defect.

\section{Miscellaneous Conditions}

Golgi impregnations of the cortex from tuberous sclerosis reveal two cell components in the cortical tubers. These include astrocytes and smaller, multipolar neurons. The neuronal component of the tubers is an aberrant primitive cell type and consists predominantly of stellate neurons. 88 They have short dendrites and sparse but definite spines. The tubers show varied structural disorganization with abnormal neuronal orientation and distribution. ${ }^{86,88,89} \mathrm{~A}$ decrease in the length of apical and 
basal dendrites of pyramidal neurons in layers 2 and 3 have been described in the cortex remote from the tubers. The horizontal extent of the dendritic fields of individual pyramidal cells is decreased. These changes are more marked in the cortex adjacent to the tubers. 83.88

Golgi studies in cortical biopsies of patients with subacute sclerosing panencephalitis have revealed abnormal pyramidal dendritic domain, spine loss, and reactive gliosis..$^{90}$ On electron microscopy, electron-dense degenerating dendrites have been observed in all cortical layers, most abundantly in layers 1,2 , and 3.91 Using immune electron microscopy, Budka et al92 showed the presence of viral antigen in such dendrites.

The basic mechanisms of epilepsy in man remain elusive but a spectrum of dendritic pathology in epileptic patients has been recognized. ${ }^{93-95}$ Scheibel and Scheibel ${ }^{93}$ studied the human hippocampal dentate complex in chronic temporal lobe epilepsy. They reported a loss of dendritic spines and development of nodular or fusiform enlargements along dendritic shafts as abnormalities characteristic of epileptic tissue. In a study of 14 human epileptogenic foci, Vaquero et al ${ }^{95}$ commented that the finding of nodular dendritic swellings was significant; they attributed the swellings to disarray of microtubular arrangement and postulated that this may lead to a mechanical distortion of the dendritic membrane and cause its depolarization. In their study, there were no other statistically significant differences in the findings, such as loss of dendritic spines, compared with findings in controls. Therefore, they concluded that the epileptic brain has neurons with a normal number of dendritic spines and angulations. However, there was no significant degree of gliosis in these areas, as would be expected in epileptic foci.

Golgi studies have been performed on certain unusual disorders including neoplasms. In a cerebral ganglioma Ferrer et al ${ }^{96}$ reported the presence of neurons of fusiform configuration as well as those with multiple dendritic processes; pyramidal-like neurons were absent. In a Golgi study of a dysplastic gangliocytoma of the cerebellum (Lhermitte-Duclos disease), Ferrer et al ${ }^{97}$ showed abnormal dendritic morphology in the proliferating cells. These cells had thick dendrites that were unbranched proximally but densely arborized distally with varicosities. Ambler and colleagues, ${ }^{98}$ who analyzed the pathology of the first familial cases of this condition, suggested that the proliferating cells were modified granule cells, because their axons were oriented toward the pial surface as are those of granule cells. Transitions between the abnormal cells and normal granule cells were also present. 98

Dendritic abnormalities have also been observed in the sudden infant death syndrome. Quattrochi et al ${ }^{99}$ and our group 100 found that the neurons of the brain stem reticular formation retained an immature dendritic pattern.

Our Golgi analysis of the medullary respiratory centers indicates that dendritic spines in these centers are increased prenatally and decreased postnatally. 100 Within the medulla oblongata, neuronal maturation occurs slightly earlier in the reticular formation than the vagal nucleus, perhaps in association with the functional development of the central respiratory control from intra- to extrauterine life.

\section{Degenerative Diseases}

There are numerous reports on dendrite pathology in normal aging and various neurodegenerative disorders. ${ }^{16,101-121}$
Traditionally, the process of aging in the human brain has been viewed as a progressive, steady decline of the neuronal population. The dendritic branching of the remaining neurons appears to be increased. These alterations in dendritic ramifications in aging and senile dementia are a function of the balance between the regressive and proliferative modeling occurring in dendritic structure. These changes are both age-related and region-specific.

Buell and Coleman 107,108 reported increased dendritic growth in layer 2 pyramidal neurons of the parahippocampal gyrus in normal elderly subjects (mean age, 79.6 years) compared with normal middle-aged adults (mean age 51.2 years) or senile dementia patients. There was a slight tendency for patients with senile dementia to have shorter, less branched dendrites than normal elderly controls. The authors suggested that the aging cortex has both regressing, dying neurons and surviving, growing neurons.

Increased dendritic extent has also been described in the granule cells of the hippocampal dentate gyrus between middle age (mean, 52.3 years) and old age (mean, 73.4 years), followed by apparent dendritic regression in very old age (mean, 90.2 years). ${ }^{117,118}$ More recently, Flood et al ${ }^{119}$ reported that dendritic extent of both apical and basal dendrites of $\mathrm{CA}_{2-3}$ pyramidal neurons did not change between middle age and very old age. Thus, there are regional variations in the dendritic changes associated with aging.

Nakamura et al ${ }^{111}$ quantitatively analyzed age-related changes of pyramidal cell basal dendrites in layers 3 and 5 of the human motor cortex. They found a decrease in the number of basal dendrites with advancing age, more prominent in layer 5 than layer 3 . Scheibel et al ${ }^{104}$ indicated that horizontally oriented dendritic components were more involved.

Dendritic abnormalities have also been observed in Alzheimer's disease (AD). In AD, the hippocampus is thought to be isolated due to pathological alterations in the entorhinal cortex and the subiculum. Mehraein et al ${ }^{102}$ showed decreased apical dendrite spines in the pyramidal cells of layer 3 and 5 in both $\mathrm{AD}$ and senile dementia, with the spine density being smaller in AD. Reduction in the dendritic arborization was also present in Purkinje cells. Scheibel and Tomiyasu 106 showed a number of changes in neurons in AD, including loss of dendritic spines and irregular swelling of the cell body and dendrites, with progressive loss of the dendrite domain culminating in cell death. Clusters of new dendrite growth developing at one or more sites along the dendritic or somal surface were also present. These clusters appeared haphazard in placement and orientation and were termed "lawless."

In an analysis of the granule cells of the dentate gyrus, deRuiter and Uylings ${ }^{121}$ showed a reduction in the thickness of the molecular layer with reduced density of dendritic spines in the middle third of the molecular layer and reduced total dendritic length. Arendt et al, ${ }^{120}$ in a morphological analysis of the nucleus basalis of Meynert, described degenerative changes including irregular swellings and fragmentations of dendrites involving both the reticular neurons and the multipolar giant neurons; in addition, the reticular neurons showed an increased cell size and increased spatial extension of the dendritic tree.

Flood et al ${ }^{118}$ analyzed the dentate granule cells in 22 patients between 43 and 95 years of age, of which five clinically had senile dementia of Alzheimer type. The senile dementia 
patients showed decreased dendritic extent compared with the age-matched control group, largely due to a reduction in mean segment length. Compared with a younger (middle-aged) nondemented group, the patients' dendritic extent was not significantly altered. Thus the senile dementia group made up for the reduced mean segment length by having more segments than the middle-aged group. These data suggest that at some time between middle age and death, the senile dementia patients had a "reactive-remodeling" response by increasing the numbers of dendrite segments. The most striking difference between normal aging and senile dementia was that the latter had reduced mean segment length compared with the control group.

Probst et al ${ }^{110}$ found that the morphology of dendrites and axons within the neuritic plaques in senile dementia of Alzheimer's type was frequently abnormal with pleomorphic outpouchings of terminal and preterminal dendritic and axonal segments, many of which contained filiform processes. Unaltered neurites were apparently found crossing the plaques. Axonal sprouting was prominent within the plaques. The neurites participating in the neuritic plaques retained contact with the parent cell. Axonal and dendritic processes were found in plaques, probably having arisen from pyramidal and nonpyramidal neuronal types. Thus, this study illustrated that local neurons of various types contributed to the plaques, and their processes may proliferate within the plaques. In Pick's disease, cortical neurons have almost no spines on their dendrites and virtually no tertiary branching of basal dendrites. ${ }^{112}$

A recent study by Catalá et al ${ }^{113}$ documented decreased numbers of dendritic spines in a group of patients with different types of dementia, including Alzheimer's, Parkinson's, Creutzfeldt-Jakob, and Pick's diseases.

Golgi impregnations of neostriatum from patients with Huntington's disease have shown striking alterations in the dendrites of medium-sized spiny neurons. Marked recurving of terminal branches and abnormalities in the numbers as well as the morphology of spines are seen. In contrast, pathological changes were rarely encountered in the medium-sized and large aspiny neurons, indicating the selective involvement of specific cell populations in this disease. ${ }^{114}$

In amyotrophic lateral sclerosis (ALS), the anterior horn cells had abnormalities of axons and dendrites. The axon remained thin where the first myelinated segment occurred, a site that normally correlated with a thickened axon. Dendrites were thin and their arborization showed poor expansion with illdefined dendritic patterns. ${ }^{115}$

In a patient with a primary degeneration of the granular layer of the cerebellum, Ferrer et al ${ }^{116}$ found that the Purkinje cells showed an abnormal association of the perikaryon and dendrites, reduction in size of dendritic arborization, absence of spiny branches, and large numbers of stubby spines and hypertrophic spines on secondary dendritic branches.

Our quantitative Golgi studies on visual cortices of Duchenne muscular dystrophy patients have revealed abnormalities in dendritic development and arborization. ${ }^{122}$ We found a significant reduction in the total dendritic length and branching in one 16-year-old patient and attenuated dendritic arborization in another 16-year-old patient.

\section{Future Considerations}

Visualization of the complete neuron through the use of the Golgi technique has permitted detection of various aspects of neuronal development, maturation, pathological alterations, and senescence. The Golgi methods are not ordinarily thought of as lending themselves to diagnostic neuropathology; however, in combination with other neurohistological and neuroanatomic tools, the method is promising. For example, if a counterstain such as Nissl staining is applied, the relative position of the impregnated neuron to other anatomic landmarks can be determined. The Golgi method may be combined with myelin stains, permitting the visualization of fiber tracts. The technique has also been modified to permit electron microscopy of Golgiimpregnated neurons. ${ }^{123-126}$ This enables one to visualize both the dendritic branching patterns and synaptic connections of a particular neuron. Combination of the Golgi and autoradiographic techniques permits recognition of neuronal morphology on subpopulations of neurons with known time of ontogeny. 127 Thus, combination techniques involving deimpregnation and counterstaining of Golgi preparations or deimpregnation followed by application of a second neuroanatomic technique will permit a more complete understanding of the morphology and physiology of dendrites and their interactions with other cell components.

\section{ACKNOWLEDGEMENT}

This paper was prepared with the assistance of the Medical Publications Department, The Hospital for Sick Children, Toronto.

\section{REFERENCES}

1. Conel JL. The postnatal development of the human cerebral cortex. Cambridge, Mass., Harvard University Press, vol I-VIII, 1939, 1941, 1947, 1951, 1955, 1959, 1963, 1967.

2. Poliakov GI. Some results of research into development of neuronal structure of the cortical ends of the analyzers in man. J Comp Neurol 1961; 117: 197-212.

3. Rabinowicz TH. The cerebral cortex of the premature infant of the 8th month. In: Purpura DP, Schade JD, eds. Growth and Maturation of the Brain. Prog Brain Res 1964; 4: $39-92$

4. Marin-Padilla M. Prenatal and early postnatal ontogenesis of the human motor cortex: a Golgi study. I. The sequential development of the cortical layers. Brain Res 1970; 23: 167-183.

5. Purpura DP. Dendritic differentiation in human cerebral cortex. Normal and aberrant developmental patterns. Adv Neurol 1975; 12: 91-116.

6. Purpura DP. Comparative physiology of dendrites. In: Quarton GC, Melnechuk T, and Schmitt FO, eds. The Neurosciences: A Study Program. New York: Rockefeller University Press 1967; 372-393.

7. Gray EG. Axo-somatic and axo-dendritic synapses of the cerebral cortex: an electron microscope study. J Anat 1959; 93: 420-433.

8. Valverde $F$. The Golgi method. A tool for comparative structural analyses. In: Nauta WJH, Ebbesson SOE, eds. Contemporary Research Methods in Neuroanatomy. New York: SpringerVerlag 1970; 12-31.

9. Scheibel ME, Scheibel AB. The rapid Golgi method. Indian summer or renaissance? In: Nauta WJH, Ebbesson SOE, eds. Contemporary Research Methods in Neuroanatomy. New York: Springer-Verlag 1970; I-11. 
10. Ramón-Moliner E. The Golgi-Cox technique. In: Nauta WJH, Ebbesson SOE, eds. Contemporary Research Methods in Neuroanatomy. New York: Springer-Verlag 1970; 32-55.

11. Scheibel ME, Scheibel AB. The methods of Golgi. I $n$ : Robertson RT, ed. Neuroanatomical Research Techniques 1978; 89-114.

12. Chan F-W. Golgi methods in the study of nerve cells: a literature review. Can J Med Tech 1979; 41: E228-236.

13. Millhouse OE. The Golgi methods. In: Heimer L, Robards MJ, eds. Neuroanatomical Tract-Tracing Methods. New York: Plenum Press 1981; 311-344.

14. Morest DK. The Golgi methods. In: Heym C, Forssmann WG, eds. Techniques in Neuroanatomical Research. Berlin: Springer 1981; 124-138.

15. Braak H, Braak E. Golgi preparations as a tool in neuropathology with particular reference to investigations of the human telencephalic cortex. Prog Neurobiol 1985; 25: 93-139.

16. Gabbott PL, Somogyi J. The 'single' section Golgi-impregnation procedure: methodological description. J Neurosci Methods 1984; 11: 221-230.

17. Williams RS, Ferrante RJ, Caviness VS. The Golgi rapid method in clinical neuropathology: the morphologic consequences of suboptimal fixation. J Neuropathol Exp Neurol 1978; 37: 13-33.

18. Ramón Y Cajal S. Histologie du système nerveux de l'homme et des vertébrés, vol 2. Paris: Maloine 1911.

19. Schade JP, van Groeningen WB. Structural organization of the human cerebral cortex. I. Maturation of the middle frontal gyrus. Acta Anat (Basel) 1961; 47: 74-111.

20. Schade JP, Meeter K, van Groeningen WB. Maturational aspects of the dendrites in the human cerebral cortex. Acta Morphol Neerl Scand 1962; 5: 37-48.

21. Marin-Padilla M. Origin of the pericellular baskets of the pyramidal cells of the human motor cortex: a Golgi study. Brain Res 1969; 14: 633-646.

22. Marin-Padilla M. Prenatal and early postnatal ontogenesis of the human motor cortex: a Golgi study. II. The basket-pyramidal system. Brain Res 1970; 23: 185-191.

23. Marin-Padilla M. Double origin of the pericellular baskets of the pyramidal cells of the human motor cortex: a Golgi study. Brain Res 1972; 38: 1-12.

24. Purpura DP. Morphogenesis of visual cortex in the preterm infant. In: Brazier MAB, ed. Growth and Development of the Brain: Nutritional, Genetic, and Environmental Factors. New York: Raven Press 1975; 33-49.

25. Purpura DP. Developmental pathobiology of cortical neurons in immature human brain. In: Gluck L, ed. Intrauterine Asphyxia and the Developing Fetal Brain. Chicago: Yearbook Medical Publishers Inc. 1977; 349-373.

26. Paldino AM, Purpura DP. Quantitative analysis of the spatial distribution of axonal and dendritic terminals of hippocampal pyramidal neurons in immature human brain. Exp Neurol 1979; 64: 604-619.

27. Paldino AM, Purpura DP. Branching patterns of hippocampal neurons of human fetus during dendritic differentiation. Exp Neurol 1979; 64: 620-631.

28. Takashima S, Chan F, Becker LE, et al. Morphology of the developing visual cortex of the human infant. A quantitative and qualitative Golgi study. J Neuropathol Exp Neurol 1980; 39: 487501.

29. Becker LE, Armstrong DL, Chan F, et al. Dendritic development in human occipital cortical neurons. Dev Brain Res 1984; 13 : 117-124.

30. Angevine $\mathrm{BJ} \mathrm{J}$ r. Development of the hippocampal region. In: Isaacson RL, Pribram KH, eds. The Hippocampus. Volume 1: Structure and Development. New York: Plenum Press 1975; 61. 94.

31. Marin-Padilla M, Marin-Padilla TM. Origin, prenatal development and structural organization of layer I of the human cerebral (motor) cortex. A Golgi study. Anat Embryol 1982; 164: 161206.

32. Seldon HL. Structure of human auditory cortex. I. Cytoarchitectonics and dendritic distributions. Brain Res 1981; 229: 277-294.

33. Seldon HL. Structure of human auditory cortex. II. Axon distribu- tions and morphological correlates of speech perception. Brain Res 1981; 229: 295-310.

34. Seldon HL. Structure of human auditory cortex. III. Statistical analysis of dendritic trees. Brain Res 1982; 249:211-221.

35. Abdel-Maguid TE, Bowsher D. Classification of neurons by dendritic branching pattern. A categorisation based on Golgi impregnation of the spinal and cranial somatic and visceral afferent and efferent cells in the adult human. J Anat 1984; 138: 689-702.

36. Marin-Padilla $M$. Number and distribution of the apical dendritic spines of the layer $\mathrm{V}$ pyramidal cells in man. J Comp Neurol 1967; 131: 475-490.

37. Jones EG, Powell TPS. Morphological variations in the dendritic spines of the neocortex. J Cell Sci 1969; 5: 509-529.

38. Takashima S, Becker LE, Chan F-W. Retardation of neuronal maturation in premature infants compared with term infants of the same postconceptional age. Pediatrics $1982 ; 69: 33-39$.

39. Marin-Padilla M. Structural abnormalities of the cerebral cortex in human chromosomal aberrations: a Golgi study. Brain Res 1972; 44: 625-629.

40. Marin-Padilla M. Structural organization of the cerebral cortex (motor area) in human chromosomal aberrations. A Golgi study. 1. $D_{1}(13-15)$ trisomy, Patau syndrome. Brain Res 1974; 66: 375-391.

41. Huttenlocher PR. Dendritic development in neocortex of children with mental defect and infantile spasms. Neurology 1974; 24 203-210.

42. Purpura DP. Dendritic spine "dysgenesis" and mental retardation. Science 1974; 186: 1126-1128.

43. Huttenlocher PR. Synaptic and dendritic development and mental defect. I $n$ : Buchwald NA, Brazier MAB, eds. Brain Mechanisms in Mental Retardation: UCLA Forum Med Sci, No. 18, New York: Academic Press 1975; 123-140.

44. Purpura DP. Normal and aberrant neuronal development in the cerebral cortex of the human fetus and young infant. In Buchwald NA, Brazier MAB, eds. Brain Mechanisms in Mental Retardation: UCLA Forum Med Sci, No. 18, New York: Academic Press 1975; 141-169.

45. Purpura DP. Pathobiology of cortical neurons in metabolic and unclassified dementias. In: Katzman R, ed. Congenital and Acquired Cognitive Disorders. New York: Raven Press 1979; 43-68.

46. Marin-Padilla M. Pyramidal cell abnormalities in the motor cortex of a child with Down's syndrome: a Golgi study. J Comp Neurol 1976; 167: 63-82.

47. Suetsugu M, Mehraein P. Spine distribution along the apical dendrites of the pyramidal neurons in Down's syndrome. A quantitative Golgi study. Acta Neuropathol (Berl) 1980; 50: 207-210.

48. Takashima S, Becker LE, Armstrong DL, et al. Abnormal neuronal development in the visual cortex of the human fetus and infant with Down's syndrome. A quantitative and qualitative Golgi study. Brain Res 1981; 225:1-21.

49. Fabregues I, Ferrer I. Abnormal perisomatic structures in nonpyramidal neurons in the cerebral cortex in Down's syndrome. Neuropathol Appl Neurobiol 1983; 9: 165-170.

50. Becker LE, Armstrong DL, Chan F. Dendritic atrophy in children with Down's syndrome. Ann Neurol 1986; 20: 520-526.

51. Williams RS, Matthyse S. Age-related changes in Down syndrome brain and the cellular pathology of Alzheimer disease. Prog Brain Res 1986; 70: 49-67.

52. Purpura DP, Suzuki K. Distortion of neuronal geometry and formation of aberrant synapses in neuronal storage disease. Brain Res 1976; 116: 1-21.

53. Williams RS, Lott IT, Ferrante RJ, et al. The cellular pathology of neuronal ceroid-lipofuscinosis. A Golgi-electronmicroscopic study. Arc Neurol 1977; 34: 298-305.

54. Purpura DP. Ectopic dendritic growth in mature pyramidal neurones in human ganglioside storage disease. Nature 1978; 276 : 520-521.

55. Braak H, Goebel HH. Pigmentoarchitectonic pathology of the isocortex in juvenile neuronal ceroid-lipofuscinosis: axonal enlargements in layer II ab and cell loss in layer V. Acta Neuropathol (Berl) 1979; 46: 79-83. 
56. Williams RS, Ferrante RJ, Caviness VS Jr. The isolated human cortex. A Golgi analysis of Krabbe's disease. Arch Neurol 1979; 36: 134-139.

57. Ferrer I, Arbizu T, Peña J, et al. A Golgi and ultrastructural study of dominant form of Kufs' disease. J Neurol 1980; 222: 183. 190.

58. Goldman F, Katz D, Rapin I, et al. Chronic $\mathrm{G}_{\mathrm{MI}}$ gangliosidosis presenting as dystonia: I. Clinical and pathological features. Ann Neurol 1981; 9: 465-475.

59. Paula-Barbosa MM, Tavares MA, Silva CA, et al. Axo-dendritic abnormalities in a case of juvenile neuronal disease. J Submicrosc Cytol 1981; 13: 657-665.

60. Paula-Barbosa MM, Tavares MA, Lavandeira MT. Axonal enlargements (meganeurites) in neuronal ceroid lipofuscinosis (NCL). Ultrastruct Pathol 1982; 3: 237-242.

61. Braak H, Braak E, Goebel HH. Isocortical pathology in type C Niemann-Pick disease: a combined Golgi pigmentoarchitectonic study. J Neuropathol Exp Neurol 1983; 42: 671-687.

62. Takashima S, Becker LE, Chan F, et al. Golgi and computer morphometric analysis of cortical dendrites in metabolic storage disease. Exp Neurol 1985; 88: 652-672.

63. Jagadha V, Halliday WC, Becker LE. The association in two siblings of infantile osteopetrosis and neuronal storage disease. Neuropathol Exp Neurol 1986; 45: 366 (abstract).

64. Becker LE, Takashima S. Dendritic structure in the leucodystrophies: a Golgi analysis of metachromatic leucodystrophy, adrenoleucodystrophy, Cockayne's disease, and PelizaeusMerzbacher disease. International Symposium on the Leucodystrophy and Allied Diseases, Kyoto, September 19-20, 1981; 37-52.

65. Fujisawa K, Nakamura A. The human Purkinje cells: a Golgi study in pathology. Acta Neuropathologica (Berl) 1982; 56: 255264.

66. Horoupian DS. 'Dystrophic' Purkinje cells in an infant. Acta Neuropathol (Berl) 1982; 57: 165-170.

67. Menkes JH, Alter M, Steigleder GK, et al. A sex-linked recessive disorder with retardation of growth, peculiar hair, and focal cerebral and cerebellar degeneration. Pediatrics 1962; 29: 764-779.

68. Aguilar MJ, Chadwick DL, Okuyama K, et al. Kinky hair disease. I. Clinical and pathological features. J Neuropathol Exp Neurol 1966; 25: 507-522.

69. Ghatak NR, Hirano A, Poon TP, et al. Trichopoliodystrophy II Pathological changes in skeletal muscle and nervous system. Arch Neurol 1972; 26: 60-72.

70. Purpura DP, Hirano A, French JH. Polydendritic Purkinje cells in $\mathrm{X}$-chromosome linked copper malabsorption: a Golgi study. Brain Res 1976; 117: 125-129.

71. Hirano A, Llena JF, French JH, et al. Fine structure of the cerebellar cortex in Menkes kinky-hair disease (X-chromosome-linked copper malabsorption). Arch Neurol 1977 34: 52-56.

72. Williams RS, Marshall PC, Lott IT, et al. The cellular pathology of Menkes steely hair syndrome. Neurology 1978; 28: 575-583.

73. Zecevic N, Rakic P. Differentiation of Purkinje cells and their relationship to other components of developing cerebellar cortex in man. J Comp Neurol 1976; 167: 27-48.

74. Bauman ML, Kemper TL. Curtailed histoanatomic development of the brain in phenylketonuria. J Neuropathol Exp Neurol 1974; 33: 181 (abstract).

75. Bauman ML, Kemper TL. Morphologic and histoanatomic observations of the brain in untreated human phenylketonuria. Acta Neuropathol 1982; 58: 55-63.

76. Richman DP, Stewart RM, Caviness VS Jr. Cerebral microgyria in a 27-week fetus: an architectonic and topographic analysis. J Neuropathol Exp Neurol 1974; 33: 374-384.

77. Stewart RM, Richman DP, Caviness VS Jr. Lissencephaly and pachygyria: an architectonic and topographical analysis. Acta Neuropathol 1975; 31: 1-12

78. Williams RS, Ferrante RJ, Caviness VS Jr. Neocortical organization in human cerebral malformations. A Golgi study. Neurosci Abstr 1975; 1: 776

79. Kristı DA. Impaired neuronal migration in cytomegalic inclusion disease: a Golgi analysis. J Neuropathol Exp Neurol 1976; 35: 369 (abstract).
80. Williams RS, Ferrante RJ, Caviness VS Jr. The cellular pathology of microgyria. A Golgi analysis. Acta Neuropathol (Berl) 1976; 36: $269-283$.

81. Ferrer I, Fernandez-Alvarez E. Lisencefalia: Agiria. Un estudio con el metodo de Golgi. J Neurol Sci 1977; 34: 109-120.

82. Caviness VS Jr, Williams RS. Cellular pathology of developing human cortex. In: Katzman R, ed. Congenital and Acquired Cognitive Disorders. New York: Raven Press 1979; 69-89.

83. Huttenlocher PR, Wollman RL: The fine structure of cerebral cortex in tuberous sclerosis: a Golgi study. Ann Neurol 1980: 8: 223 (abstract)

84. Della Giustina E, Goffinet AM, Landrieu P, et al. A Golgi study of the brain malformation in Zellweger's cerebro-hepato-renal disease. Acta Neuropathol 1981; 55: 23-28.

85. Robain O, Deonna T. Pachygyria and congenital nephrosis disorder of migration and neuronal orientation. Acta Neuropathol 1983; 60: 137-141.

86. Ferrer I, Fabregues I, Coll J, et al. Tuberous sclerosis: a Golgi study of cortical tuber. Clin Neuropathol 1984; 3: 47-51.

87. Ferrer I. A Golgi analysis of unlayered polymicrogyria. Acta Neuropathol (Berl) 1984; 65: 69-76.

88. Huttenlocher PR, Heydemann PT. Fine structure of cortical tubers in tuberous sclerosis: a Golgi study. Ann Neurol 1984; 16: 595602

89. Machado-Salas JP. Abnormal dendritic patterns and aberrant spine development in Bourneville's disease - a Golgi survey. Clin Neuropathol 1984; 3: 52-58.

90. Paula-Barbosa MM, Tavares MA, Saraiva AA. Dendritic abnormalities in patients with subacute sclerosing panencephalitis (SSPE). A Golgi study. Acta Neuropathol (Berl) 1980; 52: 7780.

91. Paula-Barbosa MM, Ruela C, Faria R, et al. Cerebral cortex dendritic degeneration in subacute sclerosing panencephalitis (SSPE). Neurology 1980; 30: 7-11.

92. Budka H, Lassmann H, Popow-Kraupp Th. Measles virus antigen in panencephalitis. An immunomorphological study stressing dendritic involvement in SSPE. Acta Neuropathol (Berl) 1982; 56: $52-62$.

93. Scheibel ME, Scheibel AB. Hippocampal pathology in temporal lobe epilepsy. A Golgi survey. In: Brazier MAB, ed. Epilepsy. Its Phenomena in Man. UCLA Forum Med Sci, No. 17. New York: Academic Press 1973; 311-337.

94. Scheibel ME, Crandall PH, Scheibel AB. The hippocampal-dentate complex in temporal lobe epilepsy. A Golgi study. Epilepsia $1974 ; 15: 55-80$

95. Vaquero J, Oya S, Cabezudo JM, et al. Morphological study of human epileptic dendrites. Neurosurg 1982; 10: 720-724.

96. Ferrer I, Ribalta T, Digon E, et al. Cerebral ganglioglioma. A Golgi study. Virchows Arch (Pathol Anat) 1983; 400: 69-75.

97. Ferrer I, Isamat F, Acebes J. A Golgi and electron microscopic study of dysplastic gangliocytoma of the cerebellum. Acta Neuropathol (Berl) 1979; 47: 163-165.

98. Ambler M, Pogacar S, Sidman R. Lhermitte-Duclos disease (granule cell hypertrophy of the cerebellum). Pathological analysis of the first familial cases. J Neuropathol Exp Neurol 1969; 28: 622-647

99. Quattrochi JJ, Baba N, Liss L, et al. Sudden infant death syndrome (SIDS): a preliminary study of reticular dendritic spines in infants with SIDS. Brain Res 1980; 181: 245-249.

100. Takashima S, Becker LE. Prenatal and postnatal maturation of medullary 'respiratory centers'. Dev Brain Res 1986; 26: 173177.

101. Scheibel ME, Lindsay RD, Tomiyasu U, et al. Progressive dendritic changes in aging human cortex. Exp Neurol 1975; 47: 392-403.

102. Mehraein P, Yamada M, Tarnowska-Dziduszko E. Quantitative study on dendrites and dendritic spines in Alzheimer's disease and senile dementia. Adv Neurol 1975; 12: 453-458.

103. Scheibel ME, Scheibel AB. Structural changes in the aging brain. In: Brody $\mathrm{H}$, Harmon D, Ordy JM, eds. Aging, vol I. New York: Raven Press 1975; 4-37.

104. Scheibel ME, Lindsay RD, Tomiyasu U, et al. Progressive dendritic changes in the aging human limbic system. Exp Neurol 1976; $53: 420-430$. 
105. Scheibel ME, Tomiyasu U, Scheibel AB. The aging human Betz cell. Exp Neurol 1977; 56: 598-609.

106. Scheibel AB, Tomiyasu U. Dendritic sprouting in Alzheimer's presenile dementia. Exp Neurol 1978; 60: 1 -8

107. Buell SJ, Coleman PD. Dendritic growth in the aged human brain and failure to grow in senile dementia. Science 1979; 206: 854856.

108. Buell SJ, Coleman PD. Quantitative evidence for selective dendritic growth in normal aging but not in senile dementia. Brain Res 1981; 214: 23-41.

109. Ferrer I, Aymami A, Rovira A, et al. Growth of abnormal neurites in atypical Alzheimer's disease. A study with the Golgi method. Acta Neuropathol (Berl) 1983; 59: 167-170.

110. Probst A, Basler V, Bron B, et al. Neuritic plaques in senile dementia of Alzheimer type: a Golgi analysis in the hippocampal region. Brain Res 1983; 268: 249-254.

111. Nakamura S, Akiguchi I, Kameyama M, et al. Age-related changes of pyramidal cell basal dendrites in layers III and V of human motor cortex: a quantitative Golgi study. Acta Neuropathol (Berl) 1985; 65: 281-284.

112. Wechsler AF, Verity MA, Rosenschein S, et al. Pick's disease. A clinical, computed tomographic, and histologic study with Golgi impregnation observations. Arch Neurol 1982; 39: 287-290.

113. Catalá I, Ferrer I, Galofré E, Fábregues I. Decreased numbers of dendritic spines on cortical pyramidal neurons in dementia: A quantitative Golgi study on biopsy samples. Hum Neurobiol 1988; 6: 255-259.

114. Graveland GA, Williams RS, DiFiglia M. Evidence for degenerative and regenerative changes in neostriatal spiny neurons in Huntington's disease. Science 1985; 227: 770-773.

115. Kato T, Hirano A, Donnenfeld H. A Golgi study of the large anterior horn cells of the lumbar cords in normal spinal cords and in amyotrophic lateral sclerosis. Acta Neuropathol (Berl) 1987; 75: 34-40.

116. Ferrer I, Sirvent J, Manresa JM, Galofré E, Fernández-Alvarez E, Pineda M. Primary degeneration of the granular layer of the cerebellum (Norman type): A Golgi study. Acta Neuropathol (Berl) 1987; 75: 203-208.

117. Flood DG, Buell SJ, DeFiore CH, Horwitz GJ, Coleman PD. Agerelated dendritic growth in dentate gyrus of human brain is followed by regression in the 'oldest old'. Brain Res 1985; 345: 366-368.
118. Flood DG, Buell SJ, Horwitz GJ, Coleman PD. Dendritic extent in human dentate gyrus granule cells in normal aging and senile dementia. Brain Res 1987; 402: 205-216.

119. Flood DG, Guarnaccia M, Coleman PD. Dendritic extent in human $\mathrm{CA}_{2-3}$ hippocampal pyramidal neurons in normal aging and senile dementia. Brain Res 1987; 409: 88-96.

120. Arendt T, Zvegintseva HG, Leontovich TA. Dendritic changes in the basal nucleus of Meynert and in the diagonal band nucleus in Alzheimer's disease - A quantitative Golgi investigation. Neurosci 1986; 19: 1265-1278.

121. de Ruiter JP, Uylings HBM. Morphometric and dendritic analysis of fascia dentata granule cells in human aging and senile dementia. Brain Res 1987; 402: 217-229.

122. Jagadha V, Becker LE. Brain morphology in Duchenne muscular dystrophy. Proceedings of the Annual Meeting of the Canadian Association of Neuropathologists, Gull Harbour Manitoba, September 1986.

123. Blackstad TW. Electron microscopy of Golgi preparations for the study of neuronal relations. I $n$ : Nauta WJH, Ebbesson SOE, eds. Contemporary Research Methods in Neuroanatomy. New York: Springer Verlag 1970; 186-216.

124. Fairén A, Peters A, Saldanha J. A new procedure for examining Golgi impregnated neurons by light and electron microscopy. J Neurocytol 1977; 6: 311-337.

125. Wouterlood FG. Light microscopic identification and photography of Golgi impregnated central nervous system neurons during sectioning for electron microscopy. Stain Technol 1979; 54: 325-329.

126. Franzini-Armstrong C, Peachey LD. A modified Golgi black reaction method for light and electron microscopy. J Histochem Cytochem 1982; 30: 99-105.

127. Somogyi P, Freund TF, Kisvárday ZF. Different types of $3 \mathrm{H}-$ GABA accumulating neurons in the visual cortex of the rat. Characterization by combined autoradiography and Golgi impregnation. Exp Brain Res 1984; 54: 45-56. 